\title{
Coffee Fun: Gamified Tool Based on the SUM Agile Development Methodology For Video Games*
}

\author{
Manuel Esteban Jaramillo Reinel" \\ Andrés Felipe Mera Tróchez ${ }^{* *}$ \\ Katerine Márceles Villalba*** \\ Gabriel Elías Chanchí Golondrino ${ }^{* * *}$
}

Received: 11/11/2019 • Accepted: 28/05/2020

https://doi.org/10.22395/rium.v20n38a10

\begin{abstract}
In recent years, serious games have been applied in different contexts of application, highlighting their contribution in the educational context. This original type article presents the design, construction and evaluation of the Coffee Fun video game. Coffee Fun is a video serious game aimed at children aged 8 to 12 years old; the game has as a theme the growing of coffee beans in a simulation environment in which each player helps the growth of this plant by a few tools provided at each level of the game; in the game, different scenarios related to coffee growing environments are presented for each of its stages in a series of levels that the player must overcome to complete the game through a process of learning and entertainment.
\end{abstract}

Keywords: agile methodology; coffee; coffee seeds; crop; fertilizers; gamification; simulation; supply; united coffee; videogame.

\footnotetext{
Paper derived from the Seminario en Innovaciones Educativas [Educational Innovations Seminar] Sinnem18, October, 2018. This research was supported by Colegio Mayor del Cauca Universitary Institution and the University of Cartagena

* Informatic Engineer. Member of the Innovation and Development in Informatics research group. Colegio Mayor del Cauca Universitary Institution. Bicentenario building - Engineerings Faculty - Colegio Mayor del Cauca. Popayán-Cauca E-mail: esteban1062@unimayor.edu.co. Orcid: https://orcid.org/0000-0001-6581-7474

** Informatic Engineer. Member of the Innovation and Development in Informatics research group. Colegio Mayor del Cauca Universitary Institution. Bicentenario building - Engineerings Faculty - Colegio Mayor del Cauca. Popayán-Cauca. E-mail: felipemera@unimayor.edu.co. Orcid: https://orcid.org/0000-0001-6016-5278

*** Master in Computer Security and Master in Maintenance Management. Member of the Innovation and Development in Informatics research group. Colegio Mayor del Cauca Universitary Institution. Bicentenario building - Engineerings Faculty - Colegio Mayor del Cauca. Popayán-Cauca E-mail: kmarceles@unimayor. edu.co. Orcid: http://orcid.org/0000-0002-4571-0714

**** Ph.D. in Telematic Engineering. E-Soluciones [E-Solutions] research group. University of Cartagena. Piedra Bolívar Campus - Engineering Faculty. Systems Engineering Program. Cartagena de Indias - Colombia. E-mail: gchanchig@unicartagena.edu.co. Orcid: https://orcid.org/0000-0002-0257-1988
} 


\title{
Coffee Fun, herramienta gamificada basada en la metodología de desarrollo ágil de videojuegos SUM.
}

\begin{abstract}
Resumen
En los años recientes, los juegos serios han sido aplicados a diferentes contextos de aplicación, resaltando su contribución en el sector educativo. En este artículo de tipo original se presenta el diseño, construcción y evaluación del videojuego Coffee Fun. Este es un juego serio orientado a niños y niñas de 8 a 12 años de edadque presenta una temática de cultivo del grano de café en un entorno de simulación, en el cual cada jugador ayuda al crecimiento de esta planta por medio de unas herramientas suministradas en cada nivel del videojuego; en este se presentan escenarios con entornos relacionados al cultivo del café para cada una de sus etapas en una serie de niveles que el jugador debe superar para completar el juego mediante un proceso de aprendizaje y entretenimiento.
\end{abstract}

Palabras claves: abonos; café; cultivos; estados del café; gamificación; metodología ágil; semillas de café; simulación; suministro; videojuego serio. 


\section{INTRODUCTION}

This project arises from the lack of care and planting which is done during the cultivation of coffee, mainly from its first stage. In this sense, and knowing the main advantages of serious games, this work proposed the development of the serious game Coffee Fun in a theme appropriation process. The development of the game Coffee Fun focused on laying activities and reseeding cafeto plants, the use of both traditional and modern tools, as well as the use of different resources such as agrochemicals or natural resources [1].

Continuing with the above, the development of the serious game focused on the cultivation of coffee seeds, taking into account the agile development methodology SUM [2], [3]. Similarly, an ethnographic study was developed, consisting of a set of interviews that allowed the collection of inputs for the construction of the serious video game scenarios. These scenarios for the serious game Coffee Fun, are formed by a set of objects and events, which were designed by using the Construct platform and the Illustrator tool. Also, this application has the ability to be ran on multiple platforms [2]. It is important to mention that the coffee bean is characterized as a business driver in different regions of Colombia. Based on the above, the proposed serious video game aims to sensitize and teach young people and children in a playful way about the protection and dissemination of traditional knowledge about coffee cultivation [4].

The paper is organized as follows: the first section presents a set of related works to research; the second section presents the methodology employed for the construction of the video game; the third section displays a user evaluation; the fourth section presents the analysis of the results obtained from the third section and, finally, the fifth section presents the conclusions and future work derived from this research.

\section{MATERIALS AND METHODS}

The fulfillment of this project is achieved through previous references which were the support for all the theoretical framework and the overall construction of the game. Here are some related works:

The work presented in [5] raises the possibility of multiple choice questions and problems that are generated by ignorance of the true extent that occurs in the use and management of a serious game in formal education of students. In this sense, the article in question raises a number of problems that arise in trying to harness ICT tools such as scaffolding teaching. Likewise, the article presents a learning model and proposes the most appropriate way to use these tools in learning.

The work presented in [6] describes a set of different video games that have been used in schools in order to improve teaching-learning processes. Additionally, this 
project describes a set of myths and realities surrounding the use of videogames by making a comparison of serious and not serious games to obtain recommendations on the use of these serious games for adequately using learning environments.

In [7], the present an investigation into formal education and the use of new technologies focused on learning. Likewise, the article states how the field of educational video games is considered a new and unexplored scenario in its entirety, which entails three main difficulties regarding its complete socialization: its recent incorporation, its educational unpopularity as it is considered a distraction and the incomplete incorporation of ICT in the family and educational environment. In addition, it presents a video game as an educational tool. The game takes as inspiration the Odyssey and shows the usefulness of serious games in education.

The project in [8] focuses on understanding the behavior of young students of High School in Granada, Spain, during their free time and specifically in the use of technological environments available in educational institutions, focusing on aspects such as communication, entertainment and education. The results of the work are analyzed for relating them with the media and civic processes in the leisure areas.

\subsection{Methodology for the construction of the game Coffee Fun}

The process of construction and development of any serious game must be through a framework to estimate the time and cost required for the construction of an efficient product.

The development of this game was made with SUM [2], [3], because it can be ran on small teams of two to seven people. This methodology is focused on short-term projects aiming towards achieving a functional product at an estimated time of 3 months, customer engagement is also considered in order to deliver a product that meets customer expectations.

The SUM methodology defines five essential phases for the development of a game [7], each phase has a defined workflow suitable for the project; risk management should be taken into account during the planning and product development for the 5 phases of the project.

With the phases defined by SUM an activity schedule is planned (see figure 1); depending on the project to make, so a list of tasks for each phase and the ideal dates for the completion of each is drafted, taking into account that in this way it is possible to achieve better control over the development of the project. 


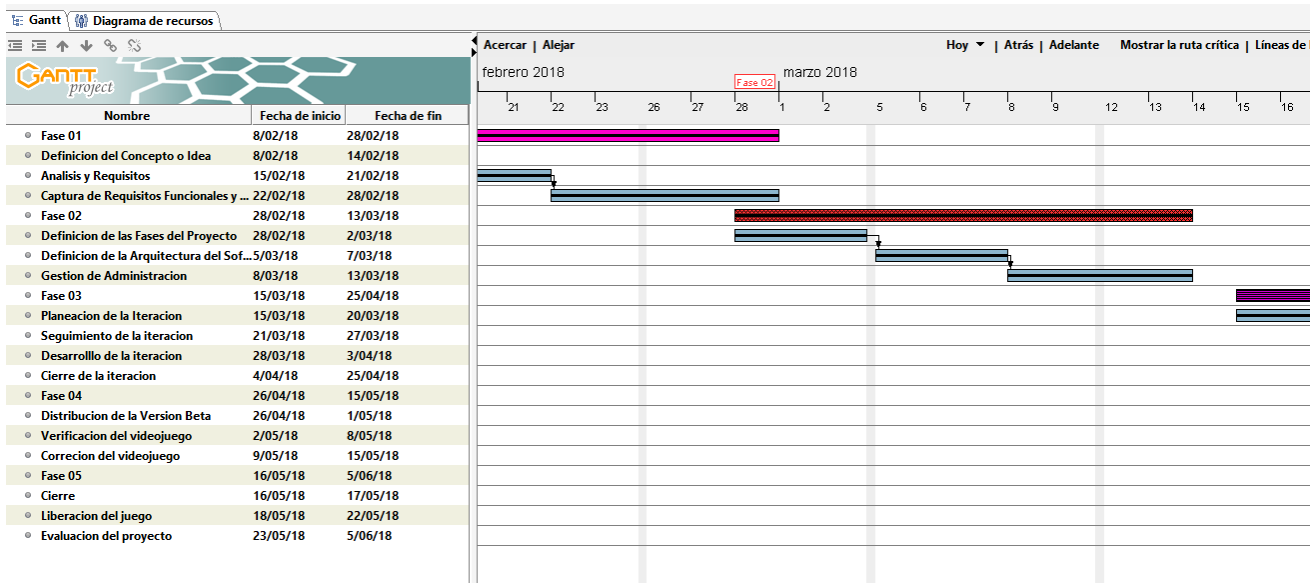

Figure 1. Work schedule stages with a SUM construction methodology for the Serious Coffee game Source: own elaboration.

A number of essential tasks for the development of the project is specified using the SUM methodology; these are:

- Phase 1: in this stage the definition of the project is done, then we proceed to requirements analysis and definition.

- Phase 2: project phases such as software architecture are defined i.e., the development environment and tools to implement. A self-managing organizational resource is done.

- Phase 3: this involves planning, monitoring, developing and closing the iteration. At this point, the game is fueled by feedback and it is built, corrected and improved.

- Phase 4: in this point, the game is in a beta version, so the game is reviewed and checked so that errors are corrected in case of detecting any.

- Phase 5: release of the game in addition to a general inspection of the project.
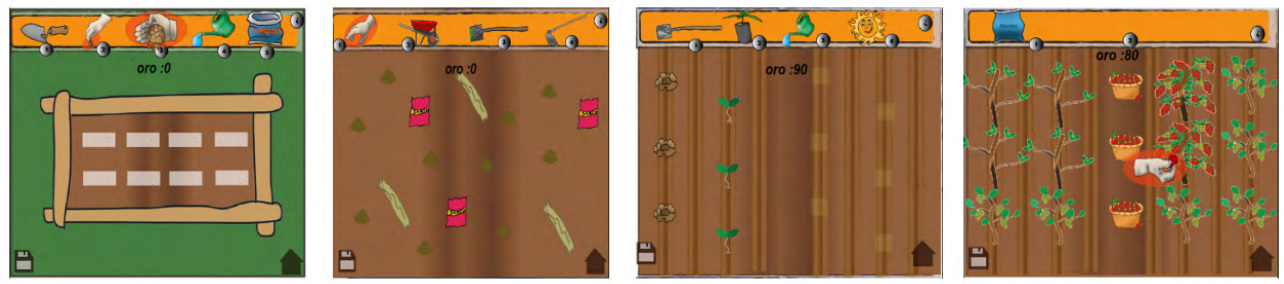

Figure 2. Coffee Fun video game

Source: Own elaboration. 


\subsection{User evaluation}

For evaluating the opinion of the players a user test was performed, focused on the execution of a pre-test questionnaire, a set of tasks and a post-test questionnaire for fourth grade children of the Liceo Nacional Alejandro de Humboldt School, in the Pomona neighborhood of the city of Popayan. Ages of users who performed the test ranged between 8 and 9 years, highlighting in them a level of cognitive retention of basic information; achieving an understanding of the dynamics and concepts mentioned in the game.

The test applied to the students consists of a pre-test questionnaire and a post-test questionnaire, which are carried out before and after the interaction with the video game, the above taking into account the conventional usability tests developed in a usability laboratory [9-12]. The pre-test questionnaire is given to the students at the beginning of the test and consists of a set of 5 single-choice questions (yes/no) related to the previous knowledge of the subject matter addressed by the serious video game. While the students were filling out the pre-test form, the work team of the project was in charge of providing assistance in case any of the students had a question about the questionnaire. Later, after the pre-test form has been filled out, inside the school's computer room, the students begin to interact with the functionalities provided in the different levels of the serious video game Coffee Fun. Within this stage, the project team does not intervene in order to allow users to interact freely with the video game. After the interaction with the game has ended, the students proceed to fill out the post-test questionnaire, which aims to evaluate the degree of appropriation of the concepts related to coffee cultivation presented by the serious video game Coffee Fun. In this way, the post-test questionnaire contains 4 yes or no questions, plus an open-ended question to know the overall opinion of the player's experience with the game.

Figures 3 and 4 display the interaction of children with the game while developing different activities under the pre-test and post-test.

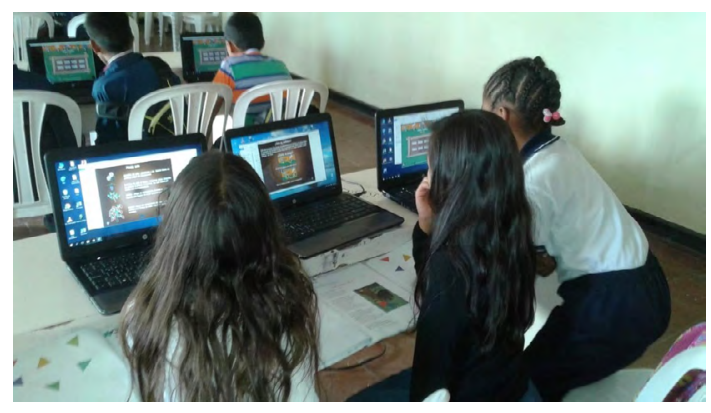

Figure 3. Participants practicing with the game Coffee Fun Source: own elaboration. 


\section{Opiniones y sugerencias:}

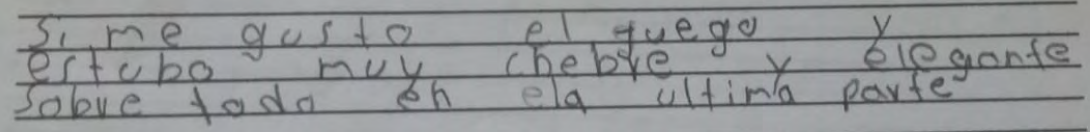

Figure 4. Recommendations obtained in the post-test questionnaire Source: own elaboration.

\section{RESULTS OF USERS}

Figure 5 shows the results of the instruments applied to children of the Liceo Nacional Alejandro de Humboldt School.

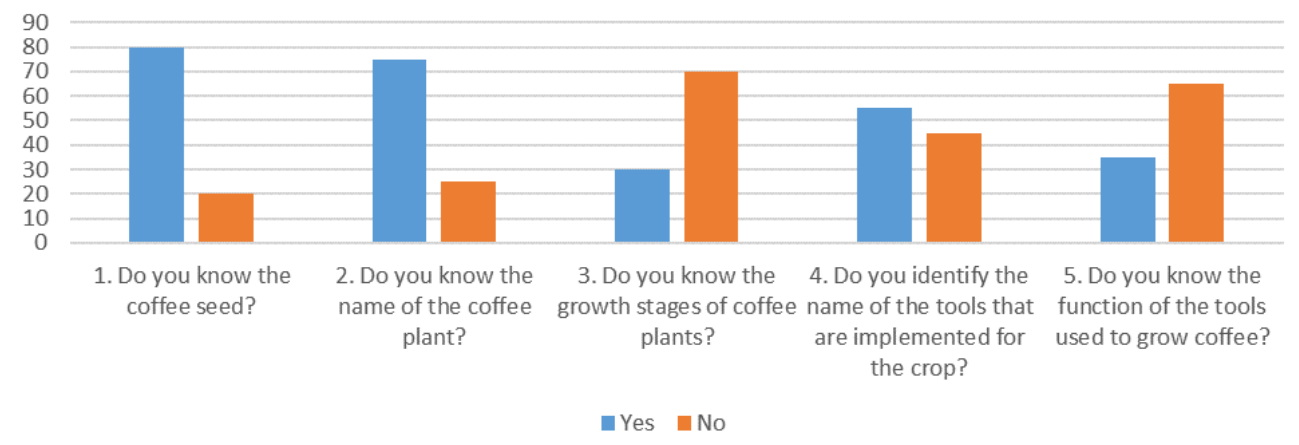

Figure 5. Pre-test results

Source: own elaboration.

In figure 5, it is possible to observe that $80 \%$ of the children know the coffee seed, while $20 \%$ of the children do not know it. Similarly, according to the pre-test questionnaire, $75 \%$ of the children knew the name of the coffee plant; however, the post-test questionnaire showed that $70 \%$ of the children did not know the real name of the coffee plant. Similarly, it can be seen that $70 \%$ of the children do not know the stages of growth of coffee plants, while $30 \%$ of the children indicated that they did. Similarly, $55 \%$ of the children identify the name of the tools used in the cultivation, while $45 \%$ of the children do not know them. Finally, $65 \%$ of the children do not know the function of the tools used for growing coffee, while $35 \%$ of the children do know them. 


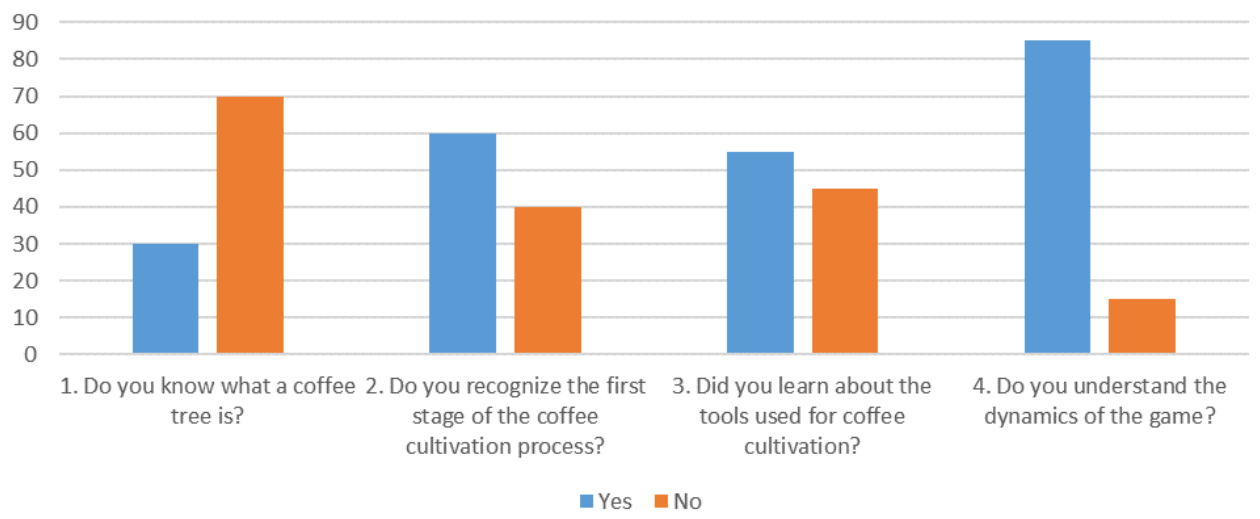

Figure 6. Post-test results

Source: own elaboration.

Figure 6 displays that $85 \%$ of the students understand the dynamics of the game Coffee Fun, this being one of the project's objectives thanks to the appropriation and the educational dynamics generated, both resulting in children learning about the coffee bean, which is a distinctive badge of the Colombian culture.

In the same way, the results show that more than $50 \%$ of the boys and girls surveyed manage to understand the video game and all its aspects such as the cultivation process, the use of the tools with their names and the seeding process.

\subsection{Tests and results of Pinelle's heuristics evaluation}

To determine the level of usability of the game, the study employed Pinelle's heuristics [13-15], which allows a quantifiable assessment of the adequacy level of the gameplay features and the video game environments.

Pinelle tests were upgraded for their assessing the Coffee Fun game by a team of experts which would be responsible for the implementation and achievement of the results.

The execution of the test was developed in a usability lab where a group of experts consisting of 6 reviewers applied the evaluation form which is comprised of 16 heuristics and each had an average of 5 questions which. These covered aspects of a serious game.

Here is an example of the questions and results of the heuristics presented. 


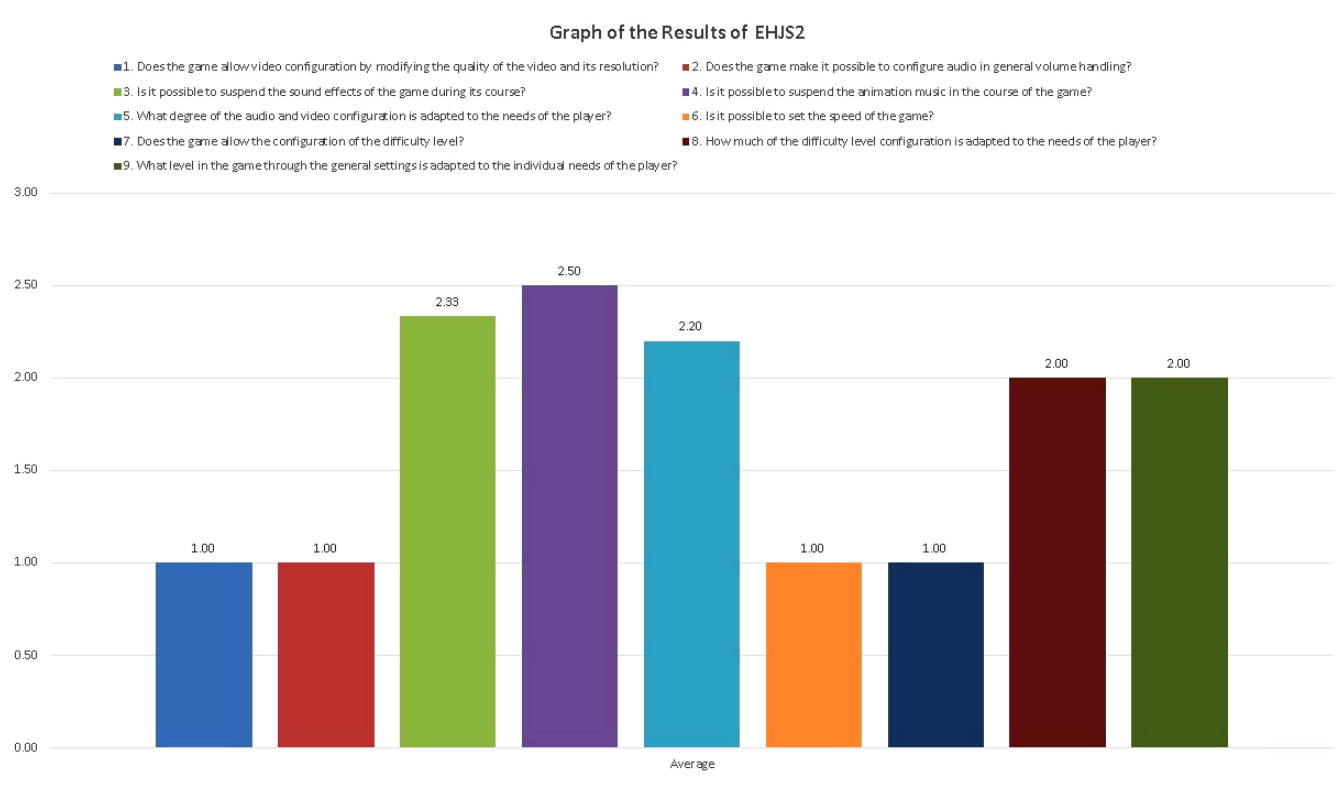

Figure 7. Results of the heuristic test

Source: own elaboration.

\section{DISCUSSION}

The dynamics of the research presented in this paper can be considered successful, since the tests carried out in the school showed that the game had an adequate degree of appropriation by the students. Likewise, given the target population of the game, it was important that the design was entertaining and simple to captivate attention and promote learning about the coffee growing process.

Children managed to complete the game and acquire knowledge related to coffee bean, keeping in mind that many of them managed to play intuitively, but at the same time there were some who did not read the instructions and executed wrong actions due to improper interpretation of the location of objects within the game.

From the results produced in the test regarding the appropriation of users regarding the coffee topic, it is possible to verify that the agile development methodology used in this study allowed the construction of a product that fully complies with the objectives pursued a serious game.

Future work aims to improve the GUI (graphic user interface) of the game, taking into account the difficulties evidenced in tests with users, specifically what to do with 
the location of objects and the adequacy of the menus so that they are more intuitive for the players.

\section{ACKNOWLEDGMENTS}

Special thanks to Engineer Alberto Collazos and Alejandro Bojorge for their contribution regarding the usability testing tool, which was a significant improvement and contribution for the video game. Likewise, the authors thank the Colegio Mayor del Cauca University Institution and the University of Cartagena for the support provided in the development of the project.

\section{REFERENCES}

[1] J. Arcila, F. F. Farfán, A. M. Moreno, L. F. Salazar, and E. Hincapié, "Sistema de producción de café en Colombia," Manizales, 2007. [Online]. Available: https://biblioteca.cenicafe.org/ handle/10778/720

[2] N. Acerenza et al., "Una metodología para el desarrollo de videojuegos," in $38^{\circ} J A I I O$ Simposio Argentino de Ingeniería de Software, 2009, pp. 171-176, [Online]. https://www. fing.edu.uy/sites/default/files/biblio/22811/asse_2009_16.pdf

[3] X. A. Murillo-Sanchez, A. L. Gutierrez-Rocha, A. W. Ibanez-Illanes, J. A. Quiroz-Perez, G. Sahonero-Alvarez, and F. R. Diaz-Palacios, "Implementation de la metodologia SUM modificada para el desarrollo de videojuegos orientados al aprendizaje en Bolivia," Cisci 2018 - Decima Septima Conf. Iberoam. en Sist. Cibern. e Informatica, Decimo Quinto Simp. Iberoam. en Educ. Cibern. e Informatica, Sieci 2018 - Memorias, vol. 2, July, pp. 144-149, 2018.

[4] C. Espinal, H. Martínez, and X. Acevedo, "La cadena del café en Colombia: una mirada global de su estructura y dinamica 1991-2005,” 2005. [Online]. Available: http://bibliotecadigital. agronet.gov.co/handle/11348/6111

[5] C. López Reventon, "El videojuego como herramienta educativa. Posibilidades y problemáticas acerca de los serious games," Apertura. Rev. innovación Educ., vol. 8, no. 1, pp. 1-15, 2016, [Online]. Available: http://www.scielo.org.mx/pdf/apertura/v8n1/20071094-apertura-8-01-00010.pdf

[6] N. Padilla, "El uso educativo de los videojuegos," 2015. [Online]. Available: http://www. juntadeandalucia.es/educacion/webportal/descargas/familias-lectoras/flash/coleccion/ resources/cariboost_files/cuaderno09.pdf

[7] B. Mainer, "El videojuego como material educativo: La Odisea," Rev. Comun. y Nuevas Tecnol., vol. 14, no. 7, pp. 1-28, 2006, doi: 10.7195/ri14.v4i1.397. 
[8] B. Muros-Ruiz, Y. Aragón-Carretero, and A. Bustos-Jiménez, "Youth's usage of leisure time with video games and social networks," Comunicar, vol. 20, no. 40, pp. 35-39, 2013, doi: 10.3916/C40-2013-02-03

[9] D. A. Albornoz, S. A. Moncayo, S. Ruano-Hoyos, G. E. Chanchí-Golondrino and K. MárcelesVillalba, "Sistema software para la ejecución de pruebas de usabilidad bajo el enfoque de mouse tracking," TecnoLógicas, vol. 22, pp. 19-31, 2019, doi: 10.22430/22565337.1511

[10] D. M. Delgado, D. F. Girón Timaná, G. E. Chanchí, and K. Márceles Villalba, "Estimación del atributo satisfacción en test de usuarios a partir del análisis de la expresión facial," Rev. Ing. Univ. Medellín, vol. 19, no. 36, pp. 13-28, Jun. 2019, doi: 10.22395/rium.v19n36a1

[11] G. E. Chanchí, W. Y. Campo, and L. M. Sierra, "Estudio del atributo satisfacción en pruebas de usabilidad, mediante técnicas de análisis de sentimientos," Rev. Ibérica Sist. e Tecnol. Informação, no. E23, pp. 340-352, 2019, Accessed: Nov. 05, 2020. [Online]. Available: https://search.proquest.com/openview/dc9c3ac1b6b131619f5c2c7bfa97c1c5/1. pdf?pq-origsite $=$ gscholar\&cbl $=1006393$.

[12] G. E. Chanchi, M. A. Ospina, and J. L. Pérez, "Sistema IoT para la monitorización de la variabilidad del ritmo cardiaco en pruebas de usabilidad," Rev. Espac., vol. 41, no. 25, p. 2020, 2020, [Online]. Available: https://www.revistaespacios.com

[13] G. E. Chanchí, M. C. Gómez Álvarez, and W. Y. Campo Muñoz, "Criterios de usabilidad para el diseño e implementación de videojuegos," Rev. Ibérica Sist. e Tecnol. Informação, no. E26, pp. 461-474, 2020.

[14] D. Pinelle, N. Wong, and T. Stach, "Heuristic Evaluation for Games: Usability Principles for Video Game Design," in CHI 2008 - Conference on Human Factors in Computing Systems, 2008, pp. 1453-1462, Accessed: Mar. 05, 2021. [Online]. Available: https://course.ccs.neu. edu/is4300f16/ssl/pinelle-chi08.pdf.

[15] S. Papaloukas, K. Patriarcheas, and M. Xenos, "Usability assessment heuristics in new genre videogames," in PCI 2009 - 13th Panhellenic Conference on Informatics, 2009, pp. 202-206, doi: 10.1109/PCI.2009.14 